\title{
Gilbert Carr, Demolierung - Gründung - Ursprung. Zu Karl Kraus' frühen Schriften und zur frühen Fackel
}

\section{Marc Lacheny}

\section{CpenEdition}

\section{Journals}

Édition électronique

URL : https://journals.openedition.org/austriaca/917

DOI : 10.4000/austriaca. 917

ISSN : 2729-0603

Éditeur

Presses universitaires de Rouen et du Havre

\section{Édition imprimée}

Date de publication : 1 décembre 2019

Pagination : 281-284

ISBN : 979-10-240-1454-8

ISSN : 0396-4590

\section{Référence électronique}

Marc Lacheny, "Gilbert Carr, Demolierung - Gründung - Ursprung. Zu Karl Kraus' frühen Schriften und zur frühen Fackel », Austriaca [En ligne], 88-89 | 2019, mis en ligne le 01 juillet 2020, consulté le 24 octobre 2022. URL : http://journals.openedition.org/austriaca/917; DOI : https://doi.org/10.4000/austriaca. 917

Ce document a été généré automatiquement le 24 octobre 2022.

Tous droits réservés 
Gilbert Carr, Demolierung - Gründung

- Ursprung. Zu Karl Kraus' frühen Schriften und zur frühen Fackel

Marc Lacheny

\section{RÉFÉRENCE}

Gilbert Carr, Demolierung - Gründung - Ursprung. Zu Karl Kraus' frühen Schriften und zur frühen Fackel, Würzburg, Königshausen \& Neumann, 2019, 885 p., ISBN :

978-3-8260-6593-4.

\section{NOTE DE L'ÉDITEUR}

L'éditeur a interrompu la publication de cette recension. 